\title{
Knowledge on Halal Food amongst Food Industry Entrepreneurs in Malaysia
}

\author{
Asyraf Hj. Ab. Rahman (Corresponding author) \\ Faculty of Social Development, Universiti Malaysia Terengganu, Malaysia \\ E-mail: asyraf@umt.edu.my \\ Wan Ibrahim Wan Ahmad \\ UUM College of Arts and Sciences, Universiti Utara Malaysia, Malaysia \\ E-mail: wiwa@uum.edu.my \\ Mohd Yusoff Mohamad \\ Faculty of Social Development, Universiti Malaysia Terengganu, Malaysia \\ E-mail: myusmo@umt.edu.my \\ Zainab Ismail \\ Faculty of Islamic Studies, Universiti Kebangsaan Malaysia, Malaysia \\ E-mail: zainab@ukm.my
}

Received: May 21, $2011 \quad$ Accepted: June 29, $2011 \quad$ Published: December 1, 2011

doi:10.5539/ass.v7n12p216

URL: http://dx.doi.org/10.5539/ass.v7n12p216

\begin{abstract}
Food industry becomes one of the main sources of income for local community in Malaysia. Thus knowledge on halal food is so crucial to be studied. This paper tends to investigate some types of traditional halal food and to analyse the entrepreneurs' knowledge on the subject. To meet these objectives, a set of questionnaire was then constructed to gather information on the issue. Using the non-probability sampling techniques, about 300 food industry entrepreneurs from the State of Terengganu and Kelantan were selected. The research indicates that there are 10 types of foods identified as traditional foods such as fish cracker, traditional Malay dessert, ketchup, fish sauce, chilli sauce, canned food, mee hoon, Malay traditional noodles, rice, and flying bread. Analysis on these traditional food industries shows that the most popular types of food industries out of 10 are rice dishes of its various kind followed by mee hoon and traditional Malay dessert as well as fish cracker. In addition, majority of the respondents have a good knowledge on halal food concept in Islam. More than half of the respondents have experiences and some exposure about halal food. Almost all of the respondents have a good knowledge on the concept of Al-Tayyibat (all kinds of lawful food) mentioned by the Quran. They were also able to differentiate between good and bad food as well as giving their full concerns over hygiene foods in terms of ways of preparing, processing and marketing.
\end{abstract}

Keywords: Halal food, Islamic hygiene, Traditional food entrepreneurs

\section{Introduction}

Recently, two food outlets operating in Kuala Lumpur were asked to stop and temporarily close their operation as they have displayed invalid halal signs that make Muslim consumers confused. This unfortunate scenario represents one of the various situations faced by common Muslim consumers in Malaysia and become a challenge for the Malaysian Department of Religious Development (JAKIM) to investigate food product that not only satisfy Muslims' daily needs but also provide them 'peace of mind' that fulfil religious teachings. Commenting on the issue Yaakob Che Man, Director for Halal Products Research Institute, Universiti Putra 
Malaysia states that there still have some imported food products in the markets which are not in line with what is prescribed under halalan and thoyiban (relating to cleanliness, nutrition, and free from toxins) (Berita Minggu, 5 Jun 2011). Despite numerous studies being made on food and biotechnology products that is said to contain many non halal inputs including pig fat, gelatin, pig DNA and alcohol, it is essential that the halal concept in regards to food be fully understood especially by food marketers and entrepreneurs.

In Malaysia, the food industries are regarded as playing a vital role in the overall national economic development as they constitute significantly in terms of income distribution and employment generation. More importantly, Malaysia has set to become the major player in providing halal product and services. The recent development and growth on the need for halal foods amongst Muslims consumers in particular, has led to the establishment of various organizations and agencies whose missions are to promote halal food, and to create halal awareness amongst Muslim consumers, as well as providing solutions to the latter's needs.

Halal is an Arabic word meaning lawful or permitted. The opposite of halal is haram, which means unlawful or prohibited. Halal foods refers to a hygiene and healthy foods accords with the teachings of the Quran and Sunnah of the Prophet, Ijma' (consensus) and Qiyas (deduction of analogy according to the Syafie or any one of the Hanafi, Maliki or Hanbali School of thought or fatawa approved by the relevant Islamic Authority) (Yusuf al-Qardhawi, 1982: 14-36; Abu Sari' Muhammad Abd Hadi, 1997: 18-20). Muslims are instructed by Allah to eat only halal foods and when in doubt to avoid it. Eating halal foods is not only good for physical health but also for spiritual development since it fulfills God's commandment. This instruction dates back to the era of Prophet Adam (pbuh) when he was clearly instructed not to eat the fruits of the forbidden tree. The Prophet's deviance of Allah's instruction led to his being punished and banished from heaven to earth (Quran, al-Baqarah: 35- 38). There are many verses in the Quran instructing Muslims to eat and drink only permitted foods as an indication of their submission and obedience to Allah. Verse 172 of Surah al-Baqarah for instance, states:

'O ye who believe! Eat of the good things wherewith We have provided you, and render thanks to Allah if it is (indeed) He whom ye worship' (2: 172)

Other verses like al-Maidah: 1, al-An'am: 145, al-A'raf: 157, al-Maidah: 4, 96, al-Furqan: 48-49 clearly signify the importance of eating halal foods with the following conditions:

a) The foods do not contain any components or products of animals that are not halal to Muslims. In case of animals, it must be slaughtered according to the Syariah (Islamic law).

b) The food does not contain any ingredients that are considered najis (filthy) in Syariah law.

c) It is not prepared using equipment that is contaminated with things that are considered najis in Syariah law and,

d) While preparing the foods, there are no other foods or elements that do not meet the requirements stated above to be around or mixed together.

While Islam provides rules and regulations over foods products so that it is produced and prepared according to God's commandment, and meeting the safety, quality and nutritional needs, similar concerns are shown by non-Muslims over the issues. In view of increasing frequency of food poisoning and public unawareness towards food security, various forms of research conducted to devise a system with in-built-safety, quality and nutritional assurance (MARDI Report. No. 193, 1999: 1). Although food safety and hygiene are given top priority, nutritional quality of food served is also important. In the view of Koc (1999), food safety and security means that 'food is available at all times; that all persons have means of access to it; that it is nutritionally adequate in terms of quality, quantity, and variety; and that it is acceptable within the given culture'.

A recent study (Endang S Soesilowati, 2010) demonstrated that being a Muslim does not guarantee that an individual's behaviour will always be Islamic, especially in consuming halal foods or even in food's preparation. The religious education experiences perhaps will also determine the level of awareness of halal food amongst Muslims. Despite the fact that Muslims's eagerness to look for halal foods and the government's concerns over the issues by setting up halal authority to monitor and to enforce halal requirement in foods in Malaysia, the nature of halal foods in food industries itself in Malaysia is still relatively unexamined. Many questions regarding the extent to which foods marketed to Muslim consumers in Malaysia considered halal remain unanswered. Information about to what extent the food industry entrepreneurs are concerned over the issues is also not available. In an attempt to fill this gap, this paper seeks to examine some concepts and definitions of halal food as indicated in the Quran and Sunnah of the prophet (pbuh). This paper also seek to analyse the most popular types of halal food industries of Malay entrepreneurs in Kelantan and Terengganu, two states in the east coast of Malaysia, and to examine the knowledge on halal food amongst Muslims in Malaysia with special 
reference to food industry entrepreneurs in Kelantan and Terengganu. This type of study is vital as it will assist the relevant authority in setting up strategies and action plan to make sure that food consumed by Muslims meets the Islamic dietary code.

\section{Materials and Methods}

This paper is part of a study conducted on halal food industry among the traditional food entrepreneurs in the state of Kelantan and Terengganu (Asyraf Hj. Ab. Rahman and Wan Ibrahim Wan Ahmad, 2004). The main objective of the previous study was to gauge the level of knowledge and understanding of halal food amongst the food industry entrepreneur in Kelantan and Terengganu. The State of Kelantan and Terengganu are very popular for the traditional industries such as batik industry, handy craft and the like. This is due to the fact that both states known to be the cradle of Malay culture, strong religious belief, and commitment to the preservation of customs, traditions and craft skills over time. The economies of both states are based on agriculture with rice, rubber, tobacco and fruits being main cash crops. In additions, fishing, fish and livestock rearing are also primarily significant.

Population of this research was the people living in these two states who actively involved in the food industry. Due to the lack of a comprehensive list of this kind of population in the area, this study employed convenience sampling to identify the target respondents. Using this sampling technique, a total of 300 traditional food industry entrepreneurs of both states were selected. The study employs both quantitative and qualitative methods to collect data. Major data for the quantitative analysis are derived from face-to-face interviews.

Data were collected during 90-minute structured interviews conducted in respondents home by professional interviewers. All interviewers were females and fluent in local dialect. The interview schedule, containing both open and closed-ended questions, covered a wide range of questions regarding demographic, socio-economic, marriage and family background, health, participation in informal activities and knowledge on halal food. Data for the qualitative analysis are derived from unstructured interviews, information from key informants, and field observation. An unstructured question used to allow respondents to describe their experiences and knowledge on the subject.

\section{Results and Discussion}

\subsection{The profile of traditional food industry entrepreneurs}

A significant portion of the entrepreneur is the middle-aged. More than half of the entrepreneurs aged between 40 - 50. Data of this study demonstrates that the average age of respondent is 42 and the greatest frequency of the age is 40 to 49 years old. Number of the entrepreneurs aged below 20 and above 50 is small. In terms of the educational status, most of the entrepreneur has a lower academic attainment. Most of them completed their education at Sijil Pelajaran Malaysia (Malaysia Certificate of Education) which is at secondary school level. Most of the entrepreneurs are married and more than half of the respondents receive monthly income RM451.00 and above and regarded them as sufficient to fulfil their daily needs.

\subsection{Traditional food industry in Kelantan and Terengganu}

The State of Kelantan and Terengganu are very popular for the traditional foods industries. This is due to the fact that both states refuted to be the cradle of Malay culture, strong religious belief, and commitment to the preservation of their customs, traditions and craft skills over time. The economies of both states are based on agriculture with rice, rubber, tobacco and fruits being main cash crops. In additions, fishing, fish and livestock rearing are also primarily significant. Batik painting is another economic strength for both states. Food industries used to be an another strength in Kelantan and Terengganu where unique and delight cuisine with popular dishes such as fried chicken, vegetable rice, trader's rice, and ghee rice being indigenous to the area. Stalls selling those foods can be found along every road throughout Kota Bharu and Kuala Terengganu as well as other towns of both states. This scenario is primarily attributed to the habits of the local people to find for outdoor dining at food stall, coupled with the hard working of food industries entrepreneurs to increase their household incomes.

The types of the traditional food industries are summarized in Table 1. From the study, there are 10 types of foods identified as traditional foods such as fish cracker, traditional Malay dessert, ketchup, fish sauce, chilli sauce, canned food, mee hoon, Malay traditional noodles, rice, and flying bread. Analysis on these traditional food industries shows that fish cracker, traditional Malay dessert, mee hoon, and rice are products that are so popular among the entrepreneurs. The most popular types of food industries out of 10 are rice dishes of its various kind followed by mee hoon and traditional Malay dessert as well as fish cracker.

Rice constitutes $46 \%$ of the food industry. This in fact is much related to the peoples' habits of both states to go for outdoor eating. There is increasingly more demand for rice, as it remains the staple food of the Malaysian 
diet though per capita consumption has dropped from 110 to $93 \mathrm{~kg}$ over the past 20 years. Kueh Traditional (Malay Traditional snacks) are snacks that easily cooked and prepared in a traditional way that has been passed down through the generations. There are variety of traditional snacks produced such as akok, apam balik and tepong pelita. They constitute $25.3 \%$ of the entrepreneurs' business involvement. This is followed by mee hoon, $25.3 \%$, and fish cracker 23\%. The rests like ketchup, flying bread and Malay traditional noodles are less significant as they considered as supportive or alternative food for local people.

\subsection{Knowledge on Halal Food amongst the Entrepreneurs}

The study aimed at measuring the knowledge level on food hygiene and the concept of halal food amongst the food industries entrepreneurs. The study is so vital as it determines how concern and serious the food industries entrepreneurs are, over the government's efforts to ensure that food products are safe and halal for consumption amongst Malaysian in general and Muslim consumers in particular. As already noted that Malaysia is a Muslim country which adheres strictly to religious regulations towards the types of food that can be sold and consumed by Muslim consumers, which comprise more that $60 \%$ of the total population of Malaysia.

Identifying the knowledge level on halal concept amongst the entrepreneurs concerned would perhaps assist relevant agencies to improve regulations towards types of food and beverage produced so that they are in accordance with Islamic teachings. There are several laws pertaining to Halal exists with the jurisdiction under various parties. One of them is the Trade Description Act 1972-Trade Description Order (Use of Expression Halal 1975) under the Ministry of Domestic Trade, Cooperatives and Consumerism. The others are the Food Act 1983 under the Health Ministry that covers cleanliness and safety of the contents and the Animal Importation Order 1962 under the Agriculture and Agro based Industries Ministry that requires the animals to be slaughtered according to Islamic ways.

In terms of the respondents' knowledge on halal food products and ways they were prepared and marketed, the results are summarized in Table 2. To measure the respondents' knowledge on halal food products, this study provide an instrument consisting of eight items as listed in the table. All items are related to the conditions of food which believed to be unlawful from Islamic perspectives. In the context of cooking oil mixed with mice or frog for instance, $98 \%$ of the respondents believe they are unlawful. Similar situation happen to foods added with alchohol for long lasting storage, whereby $98 \%$ of the respondents consider them as unlawful and should be avoided for consuming. The remaining statement also provide similar results when their response are almost close to $100 \%$.

From the questionaires shown in Table 2, almost all of the respondents have a good knowledge on halal or permissible foods in Islam. They are aware and noted that foods products containing unslaughtered or diseased animals are forbidden according to Muslim rites. A similar case, where foods prepared and added with alcohol for long lasting storage are also forbidden in their views. In terms of foods processed or manufactured using equipment that is contaminated with things considered najis (e.i. cutting or slicing pork), $98.3 \%$ agreed upon its prohibition. From the study, it is also noted that the respondents are aware upon foods often refered as mashbooh, which is doubtful or questionable. Result shows that more than $98 \%$ are aware and conscious over conditions of foods which is questionable in terms of its hygene and halal. In this context, majority of the respondents have a firm belief that any type of foods which bring about a confusion (syubhah) must be avoided as in the case of foods surrounded by dogs while the food owners are no longer sure on its' hygiene.

The findings of the study is also supported by the information from unstructed interviews with 10 sub-samples seleted from the similar group. Ini this context, they are asked with several questions concerning their personal experince regarding the knowledge on halal and hygien concepts such as (1) do you have any experience being exposed to any praise or Quranic verses suggesting the importance of preserving food hygiene?, (2) do you ever read over Quranic verses or Hadith mentionaing the food hygiene, (3) do you understand meanings of the Quranic verses related to the importance of food hygiene?, (4) do you know that there is an agency responsible to monitor halal food in our society?, (5) do you know that there are halal and haram foods available in the market?, and (6) do you ever intend to memories the Quranic verses or Hadith about halal food?.

For question (1), majority of the respondents understand the Quranic injunction on the importance of the preserving food hygiene. Majority of the respondents also notice the availability of lawful and unlawful food in the market. But coming to their knowledge of the agencies responsible for monitoring halal food in society, many of them are not aware and even do not understand the roles and functions of the agencies related to halal enforcement. This suggests that people of the states of Kelantan and Terengganu have well exposure on the Islamic teachings. This result also shows that the government supports and initiatives towards the realization of the halal food in the market contributed to this positive result and response. 


\section{Conclusion}

The study revealed some knowledge on halal food amongst food industry entrepreneur in Kelantan and Terengganu. To summarize, halal food means food permitted under the Syariah (Islamic law) and which fulfill certain conditions set by the Quran and Hadith of the Prophet (pbuh). A total of 300 food industry entrepreneurs from Kelantan and Terengganu were selected as respondents and the majority of them are female. Out of 10 types of food industries, nasi (rice dishes) become the most popular industry among the entrepreneurs. Almost all of the entrepreneurs have a good knowledge and understanding about food hygiene. In terms of the concepts of halal food, the study revealed that the majority of the respondents have a good knowledge on halal foods including ways it is processed, prepared and marketed. This also includes their awareness on food products often referred to as mashbooh (doubtful or questionable). The scenario is due to the surrounding environment of both states that still preserve the traditional culture and religious values, coupled with the continuous government effort to ensure that food sold and consumed by the Muslims adhere strictly to religious regulations. The study focuses only on the entrepreneurs in the State of Terengganu and Kelantan, and thus, result of the study may not be possible to generalize to entrepreneurs of other states particularly those living in urban and industrialized areas. A new study is therefore vital to look at those entrepreneurs' knowledge, their awareness and understanding of the Halal concept. This is important because the consumer particularly Muslim consumers become more halal concious and will only be looking for products that not only satisfy their personal needs but also give them 'peace of mind'.

\section{References}

Abu Sari’ Muhammad Abd Hadi. (1997). Hukum makanan dan sembelihan dalam pandangan Islam, (alih bahasa). Bandung: Trigenda Karya.

Asyraf Hj. Ab. Rahman \& Wan Ibrahim Wan Ahmad. (2004). Kefahaman mengenai makanan halal di kalangan pengusaha sektor tidak formal: Kes industri makanan tradisional di Kelantan dan Terengganu. Unpublished research report. Kuala Terengganu: KUSTEM

Berita Minggu. (2011). 5 Jun.

Endang S Soesilowati. (2010). Business opportunities for halal products in the global market: Muslim consumer behaviour and halal food consumption. Journal of Indonesian Social Sciences and Humanities, Vol. 3, 151-160.

Koc, Mustafa, ed. (1999). For hunger-proof cities: Sustainable urban food-systems. Ottawa: International Development Research Center.

MARDI. (1999). Meeting the safety, quality and nutritional needs of mass catering services for residential institutes. MARDI Reports, Kuala Lumpur: MARDI.

The Holy Quran.

Yusuf al-Qardhawi. (1982). Halal dan Haram dalam Islam. (The Lawful and Prohibited in Islam). Jakarta: PT. Bina Ilmu. 
Table 1. Distribution of Traditional Food Industry In Kelantan and Terengganu

\begin{tabular}{|l|l|l|}
\hline Type of Industry & Total & Percentage \\
\hline Fish cracker & 69 & 23.0 \\
Traditional Malay dessert & 76 & 25.3 \\
Ketchup & 14 & 4.7 \\
Fish sauce & 9 & 3.0 \\
Chilli sauce & 22 & 7.3 \\
Canned food & 4 & 1.3 \\
Mee hoon & 76 & 25.3 \\
Malay traditional noodles & 28 & 9.3 \\
Rice & 139 & 46.3 \\
Flying bread & 27 & 9.0 \\
Others & 34 & 11.3 \\
\hline Total & 300 & 100.0 \\
\hline
\end{tabular}

Table 2. Distribution of Knowledge on Halal and Hygiene Concepts amongst Entrepreneur

\begin{tabular}{|c|l|c|c|c|}
\hline No. & \multicolumn{1}{|c|}{ Conditions of Foods } & Halal & $\begin{array}{c}\text { Not } \\
\text { Halal }\end{array}$ & Not Sure \\
\hline 1. & Cooking oil mixed with mice or frog & - & 98.3 & 1.7 \\
\hline 2. & Foods added with alchohol for long lasting storage & 0.3 & 98.0 & 1.7 \\
\hline 3. & Beverage mixed with milk (pig) & - & 98.3 & 1.7 \\
\hline 4. & Same knife used for cutting port and beaf & - & 98.3 & 1.7 \\
\hline 5. & Foods mixed with preservative made from unslaughtered animal fat & - & 98.3 & 1.7 \\
\hline 6. & $\begin{array}{l}\text { Foods verdors who left their food stuffs for a while and return to find } \\
\text { dogs surrounding the foods }\end{array}$ & 0.3 & 98.0 & 1.7 \\
\hline 7. & Beaf being stored with pork in the same refregerator/container & 1.3 & 97.0 & 1.7 \\
\hline 8. & Canned Sardines exceeding two years or more & 0.7 & 97.7 & 1.7 \\
\hline
\end{tabular}

